\section{Synergistic effect of cytokinins on in vitro propagation of Stereospermum suaveolens using nodal explants}

\author{
Darshini R. Trivedi, Aruna G. Joshi* \\ Department of Botany, Faculty of Science, The Maharaja Sayajirao University of Baroda, Vadodara \\ 390002, India \\ ${ }^{\star}$ Corresponding author, E-mail: aruna.joshi-botany@msubaroda.ac.in
}

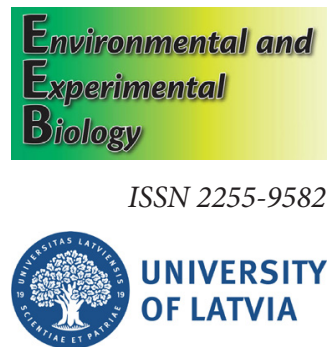

\begin{abstract}
The Stereospermum suaveolens DC. is one of the important medicinal tree species and also one of the important constituents of Dashmoolarisht. Owing to its importance an attempt was made to perform in vitro regeneration from nodal explants. Cultures were established by placing the nodal explants on Murashige and Skoog's (MS) and Woody Plant media fortified with different combinations of cytokinins. The in vitro shoots developed were excised into single in vitro nodes and then utilised for multiplication of shoots. Among the various combinations tested in both of the media, the MS medium fortified with benzylaminopurine $(8 \mu \mathrm{M})+$ thidiazuron $(0.2 \mu \mathrm{M})$ proved to be effective in inducing a maximum of 10.2 number of shoots by the end of the fifth subculture. In vitro rooting of shoots was best achieved in $1 / 2$ MS liquid medium fortified with indolebutyric acid $(2.5 \mu \mathrm{M})$, with the highest number of roots $(9.3)$ in $100 \%$ cultures. Well rooted in vitro plantlets were successfully hardened under greenhouse conditions, resulting in $100 \%$ survival of plants after four weeks of transfer to cocopeat/soil substrate.
\end{abstract}

Key words: cytokinins, cocopeat, in vitro, Murashige and Skoog's medium, nodal explant, Stereospermum suaveolens, Woody Plant Medium.

Abbreviations: AC, activated charcoal; BAP, 6-benzylaminopurine; IBA, indolebutyric acid; KN, kinetin; MS, Murashige and Skoog's medium; NAA, napthaleneacetic acid; TDZ, thidiazuron; WPM, Woody Plant Medium.

\section{Introduction}

Trees are known to be slow-growing, have a longlife span, and they are sexually self-incompatible and highly heterozygous plants (Singh et al. 2002; Giri et al. 2004). Increasing demands of humankind are forcing indiscriminate harvest of forest trees for their various parts. However, tree propagation by conventional techniques is time-consuming, labour-intensive, and season-specific, thus making the availability of a large number of plants for plantation or afforestation a complex and challenging task (Dhawan, Saxena 2004). Hence, to cope with this alarming situation, tissue culture technology has become a boon and opened extensive research areas for biodiversity conservation (Sharma et al.2010).

In vitro propagation is commonly used to conserve trees, and it depends on various factors like explant, medium, and plant growth regulators. The type of explant is one of the essential factors in optimising regeneration protocol. Various explants are utilised for regeneration, but axillary shoot proliferation directly through the nodal explant is a reliable and preferred method for clonal propagation of forest tree species for the production of true-to-type plants.
Each culture passage results in the formation of many propagules from a single explant (Batra et al. 2000). In vitro growth of plants is also affected by the composition of the culture medium. Murashige and Skoog's (MS) medium is widely used for the regeneration of many tree species like Magnolia sirindhorniae (Cui et al. 2019), Punica granatum (Murkute et al. 2004), and Bauhinia racemose (Sharma et al. 2017). Woody Plant Medium (WPM) is also equally effective for shoot regeneration and multiple shoot formation in trees like Terminalia bellerica (Rathore et al. 2008), Shorea robusta (Singh et al.2014), Pongamia pinnata (Tan et al. 2018) and Semecarpus anacardium (Panda et al. 2016) etc. Plant growth regulators are equally important for the shoot proliferation (Van Staden et al. 2008). Cytokinins are known to overcome apical dominance and stimulate lateral bud to develop into shoot (Mahadevappa et al. 2014). Especially 6-benzylaminopurine (BAP) and thidiazuron (TDZ) are the mostly used cytokinins for multiplication of shoots (Girgzde, Samsone 2017).

In the present study Stereospermum suaveolens was selected for its in vitro propagation. It is a deciduous forest tree belonging to the family Bignoniaceae. The plant is known for its various medicinal properties and is widely 
used in Ayurvedic preparations like Dashmoolarisht and Chyawanprash. The whole tree is uprooted for the collection of roots and other parts. The continued destructive harvesting of the species has caused a gradual reduction of its population in natural conditions (Behera et al.2019). Thus, it has been placed under the threatened category (Yashoda et al.2004). Even the natural propagation of the plant through seed is tedious, as fruit capsules of this tree species contain large membranous winged seeds, which are easily carried away by winds and hence seed collection becomes difficult, and it also has a low percentage of seed germination (Baul 2006). Thus initially, seed germination studies were carried out to determine a suitable substrate in which many seedlings can be developed (Trivedi, Joshi 2014a). Utilising seedling (cotyledonary node) explants and nodal explants, preliminary studies on effect of a single cytokinin on in vitro regeneration from these explants had been carried out (Trivedi, Joshi 2014b). Therefore, further studies to evaluate the synergistic effect of cytokinins on the nodal explants was necessary, to develop a complete protocol for the in vitro propagation of this important species.
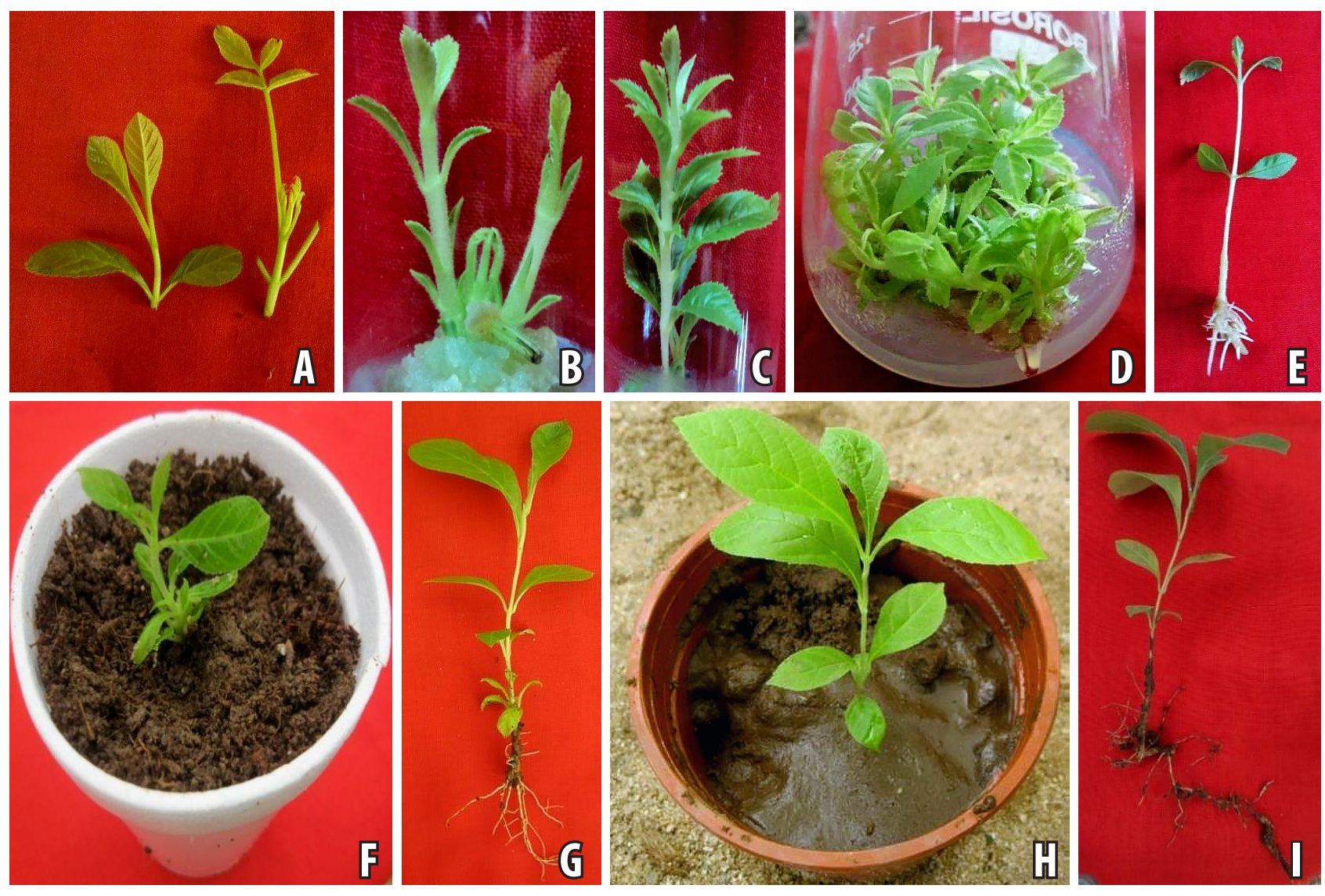

Fig. 1. In vitro propagation in S. suaveolens. A, young nodal explant. B, shoot induction in $\mathrm{MS}+\mathrm{BAP}(4 \mu \mathrm{M})+\mathrm{KN}(4 \mu \mathrm{M})$ after four weeks. C, shoot induction in WPM + BAP $(2 \mu \mathrm{M})+\mathrm{KN}(2 \mu \mathrm{M})$ after four weeks. D, multiple shoot formation in MS + BAP $(8 \mu \mathrm{M})$ $+\operatorname{TDZ}(0.2 \mu \mathrm{M})$ from in vitro nodes after fifth subculture. E, root induction in $1 / 2$ MS liquid + IBA $(2.5 \mu \mathrm{M})$ after four weeks. F, plantlet transferred to cocopeat/soil filled cups. G, increase in shoot and root growth with emergence of new leaves after four weeks of transfer. $\mathrm{H}$, plant growth in plastic pot filled with soil after eight weeks. I, well-developed plant ready to be transferred in garden pots. 
served as the control. These media were also fortified with different concentrations of BAP or kinetin $(\mathrm{KN})(2$, $4,8 \mu \mathrm{M})$ and TDZ $(0.1,0.2,0.25 \mu \mathrm{M})$ in combinations for establishment of cultures. $\mathrm{pH}$ of each media was adjusted to 5.8 and solidified with $0.8 \%$ agar (SRL, India) before autoclaving at $103 \mathrm{kPa}$ and $121^{\circ} \mathrm{C}$ for $25 \mathrm{~min}$. Data were recorded for percent response, number of shoots and number of in vitro nodes after every four weeks. All of the cultures were incubated at $25 \pm 2{ }^{\circ} \mathrm{C}$ under a $16 / 8 \mathrm{~h}$ (light/ dark) photoperiod in the culture room.

\section{Shoot multiplication and in vitro rooting of shoots}

In vitro shoots that developed were excised into single nodal segments and these in vitro nodes were used as propagules to multiply shoots. They were subcultured and transferred in the same combinations of media for shoot multiplication. Data for percent response and shoot number were recorded after every eight weeks of subculture.

Healthy elongated in vitro shoots $(4$ to $6 \mathrm{~cm}$ ) were selected and placed in rooting media. Initially, the leaves from the lower two nodes were excised, and then the shoots were placed in sterile water and after that dipped in bavistin (100 $\mathrm{mg} \mathrm{L}^{-1}$ ) solution for one minute. After this, the in vitro shoots were transferred to half and full-strength MS (liquid and static) media fortified with different concentrations of indolebutyric acid (IBA) or napthaleneacetic acid (NAA) $(0,1,2,2.5,5 \mu \mathrm{M})$ for in vitro root induction. Data for percent response, number of roots and root length were recorded after four weeks.

\section{Hardening of plantlets}

Plantlets that were developed under laboratory conditions were placed under greenhouse conditions for hardening. These in vitro plantlets were removed from media, the roots were washed with sterile water and then transferred to planting substrates. Different substrates like cocopeat, sand, soil were utilised individually or in combinations like cocopeat/soil (1:1), cocopeat/sand (1:1), cocopeat/sand/soil $(1: 1: 1)$. Each substrate $(80 \mathrm{~g})$ was filled in thermocol cups and then the plantlets were placed in it and covered with perforated polythene bags to ensure humidity. The plantlets were watered every alternate day till one month. The initial growth data were assessed for the following parameters: shoot length, root length and plant height. After four weeks, percentage survival and the growth parameters like final shoot and root length, plant height, number of new leaves and their length were recorded.

The plants from the respective substrate were transferred to plastic pots containing soil for their further growth and development and then kept in the greenhouse. These pots were initially covered with polythene bags to maintain humidity and after five days they were removed. The plants were irrigated, monitored for growth and then placed in pots filled with garden soil for two months and later transferred to natural sunlight conditions for further growth.

\section{Statistical analysis}

The mean \pm standard error was calculated for each combination and the data were analysed using one way analysis of variance followed by mean separation using the Duncan's multiple range test at a 5\% level of significance ( $p$ $\leq 0.05$ ). Six replicates were used and a single explant was a replicate and the experiments were repeated twice.

\section{Results}

\section{Establishment and multiplication of shoots}

When the nodal explants were cultured in MS and WPM basal medium (control) and fortified with cytokinins, significant differences were observed. The explants failed to form shoots in MS basal medium, whereas in WPM basal medium only $50 \%$ of explants responded after four weeks. To improve the morphogenic response, both media were fortified with a combination of two different cytokinins. The presence of cytokinins had a significant effect on percent shoot formation. Among all the combinations tried, $100 \%$ explants responded with an average of 1.5 shoots per explant (Fig. 1A) in MS medium supplemented with BAP (4 $\mu \mathrm{M})+\mathrm{KN}(4 \mu \mathrm{M})$ and BAP $(2 \mu \mathrm{M})+\mathrm{TDZ}(0.2 \mu \mathrm{M})$. Shoots elongated with a maximum of 3.3 in vitro nodes in MS medium containing BAP $(8 \mu \mathrm{M})+\mathrm{TDZ}(0.2 \mu \mathrm{M})$ after four weeks (Table 1). Similarly, WPM medium supplemented with BAP and $\mathrm{KN}$ combinations were effective for shoot induction where BAP $(4 \mu \mathrm{M})+\mathrm{KN}(8 \mu \mathrm{M})$ resulted in 1.3 shoots per explant, which was comparatively less than MS medium combinations. However, maximum in vitro nodes (4.3) were observed in WPM medium supplemented with BAP $2 \mu \mathrm{M}+\mathrm{KN} 2 \mu \mathrm{M}$ (Fig. 1C) (Table 1).

To achieve multiplication, in vitro shoots were excised into a single in vitro node and placed in only those combinations for which there was a 50\% response (after four weeks). Observations after eight weeks revealed MS medium to be more effective than WPM medium (Fig. 2). The in vitro nodes placed in MS supplemented with BAP $(4 \mu \mathrm{M})+\mathrm{KN}(2$ and $4 \mu \mathrm{M})$ failed to enhance the shoot number and the axillary bud proliferated into a shoot in only $33 \%$ of cultures. MS medium containing the synergistic combination of BAP $(4 \mu \mathrm{M})+\mathrm{KN}(8 \mu \mathrm{M})$ proved to be effective in enhancing the percent response up to $67 \%$, with a slight increase in number of shoots (1.5), whereas BAP $(8 \mu \mathrm{M})+\mathrm{KN}(2 \mu \mathrm{M})$ resulted in poor response. When BAP $(8 \mu \mathrm{M})$ was combined with TDZ $(0.2 \mu \mathrm{M})$ and supplemented in MS medium, it enhanced the shoot number to 2.2 (Fig. 2). Similarly, there was an increase in number with an average of 2.0 shoots in presence of $\mathrm{KN}$ ( 8 $\mu \mathrm{M})$ and TDZ $(0.2 \mu \mathrm{M})$.

The WPM medium fortified with the $\mathrm{KN}(2 \mu \mathrm{M})$ and $\operatorname{TDZ}(0.2,0.25 \mu \mathrm{M})$ combination resulted in poor response with only single shoot formation (Fig. 2).

By the end of the second subculture there was no 
Table 1. Effect of cyokinins on shoot induction from nodal explants of S. suaveolens after four weeks. ${ }^{*}$ Values represent mean \pm S.E of six replicates in each experiment. Means values followed by different superscript letters within a column are significantly different at $\mathrm{p} \leq 0.05$ according to Duncan's Multiple range test.

\begin{tabular}{|c|c|c|c|c|c|c|c|c|}
\hline \multicolumn{3}{|c|}{ Cytokinin $(\mu \mathrm{M})$} & \multicolumn{3}{|c|}{ MS medium } & \multicolumn{3}{|c|}{ WPM medium } \\
\hline BAP & $\mathrm{KN}$ & TDZ & $\begin{array}{l}\text { Responding } \\
\text { explants (\%) }\end{array}$ & $\begin{array}{c}\text { Number of } \\
\text { shoots per } \\
\text { explant }\end{array}$ & $\begin{array}{l}\text { Number of in } \\
\text { vitro nodes }\end{array}$ & $\begin{array}{l}\text { Responding } \\
\text { explants (\%) }\end{array}$ & $\begin{array}{c}\text { Number of } \\
\text { shoots per } \\
\text { explant }\end{array}$ & $\begin{array}{l}\text { Number of in } \\
\text { vitro nodes }\end{array}$ \\
\hline 0 & 0 & 0 & 0 & 0.0 & 0.0 & 50 & $0.5 \pm 0.3 \mathrm{abc}$ & $0.5 \pm 0.3 \mathrm{a}$ \\
\hline 2 & 2 & - & 100 & $1.0 \pm 0.0 \mathrm{cde}$ & $1.5 \pm 0.2$ abcdef & 100 & $1.0 \pm 0.0$ cde & $4.3 \pm 0.3 \mathrm{~h}$ \\
\hline 2 & 4 & - & 67 & $0.7 \pm 0.2 \mathrm{bcd}$ & $2.2 \pm 1.1 \mathrm{bcdef}$ & 67 & $0.7 \pm 0.2$ abcde & $1.8 \pm 0.6 \mathrm{abcdefg}$ \\
\hline 2 & 8 & - & 67 & $0.7 \pm 0.2 \mathrm{bcd}$ & $1.7 \pm 0.7$ abcdef & 100 & $1.3 \pm 0.2 \mathrm{e}$ & $2.8 \pm 0.4$ efgh \\
\hline 4 & 2 & - & 83 & $0.8 \pm 0.2 \mathrm{bcd}$ & $3.0 \pm 0.7 \mathrm{ef}$ & 67 & $0.7 \pm 0.2$ abcde & $1.7 \pm 0.7 \mathrm{abcdefg}$ \\
\hline 4 & 4 & - & 100 & $1.5 \pm 0.3 \mathrm{e}$ & $2.8 \pm 0.5 \mathrm{def}$ & 100 & $1.3 \pm 0.2 \mathrm{e}$ & $1.3 \pm 0.2$ abcdef \\
\hline 4 & 8 & - & 100 & $1.3 \pm 0.2 \mathrm{de}$ & $2.5 \pm 0.7 \mathrm{cdef}$ & 100 & $1.3 \pm 0.2 \mathrm{e}$ & $3.3 \pm 0.3 \mathrm{gh}$ \\
\hline 8 & 2 & - & 100 & $1.3 \pm 0.2 \mathrm{de}$ & $2.5 \pm 0.4 \mathrm{cdef}$ & 33 & $0 . \pm 0.2 \mathrm{abcde}$ & $0.5 \pm 0.3 \mathrm{abc}$ \\
\hline 8 & 4 & - & 0 & $0.0 \pm 0.0 \mathrm{a}$ & $0.0 \pm 0.0 \mathrm{a}$ & 50 & $1.0 \pm 0.5 \mathrm{cde}$ & $1.2 \pm 0.5$ abcdef \\
\hline 8 & 8 & - & 67 & $0.7 \pm 0.2 \mathrm{bcd}$ & $0.7 \pm 0.2 \mathrm{abc}$ & 33 & $0.3 \pm 0.2 \mathrm{abc}$ & $2.2 \pm 1.4$ bcdefg \\
\hline 2 & - & 0.1 & 33 & $0.7 \pm 0.4 \mathrm{bcd}$ & $0.5 \pm 0.3 \mathrm{ab}$ & 67 & $0.7 \pm 0.2$ abcde & $1.3 \pm 0.5$ abcdef \\
\hline 2 & - & 0.2 & 100 & $1.5 \pm 0.2 \mathrm{e}$ & $1.2 \pm 0.2$ abcde & 83 & $0.8 \pm 0.2$ bcde & $0.8 \pm 0.2$ abcde \\
\hline 2 & - & 0.25 & 66 & $0.7 \pm 0.2 \mathrm{bcd}$ & $0.7 \pm 0.2 \mathrm{abc}$ & 50 & $0.5 \pm 0.2 \mathrm{abcd}$ & $1.3 \pm 0.7 \mathrm{abcdef}$ \\
\hline 4 & - & 0.1 & 83 & $0.8 \pm 0.2 \mathrm{bcd}$ & $0.8 \pm 0.2 \mathrm{abc}$ & 50 & $0.5 \pm 0.2 \mathrm{abcd}$ & $0.8 \pm 0.4$ abcde \\
\hline 4 & - & 0.2 & 83 & $0.8 \pm 0.2 \mathrm{bcd}$ & $1.0 \pm 0.3 \mathrm{abcd}$ & 66 & $0.7 \pm 0.2$ abcde & $0.7 \pm 0.2 \mathrm{abcd}$ \\
\hline 4 & - & 0.25 & 67 & $0.7 \pm 0.2 \mathrm{bcd}$ & $0.7 \pm 0.2 \mathrm{abc}$ & 33 & $0.3 \pm 0.2 \mathrm{abc}$ & $0.3 \pm 0.2 \mathrm{ab}$ \\
\hline 8 & - & 0.1 & 83 & $1.0 \pm 0.3 \mathrm{cde}$ & $2.3 \pm 0.6 \mathrm{abc}$ & 83 & $1.0 \pm 0.3 \mathrm{cde}$ & $1.6 \pm 0.5 \mathrm{abcdefg}$ \\
\hline 8 & - & 0.2 & 83 & $0.8 \pm 0.2 \mathrm{bcd}$ & $3.3 \pm 1.3 \mathrm{f}$ & 33 & $0.3 \pm 0.2 b c$ & $0.3 \pm 0.2 \mathrm{ab}$ \\
\hline 8 & - & 0.25 & 67 & $0.7 \pm 0.2 \mathrm{bcd}$ & $1.0 \pm 0.4 \mathrm{abcd}$ & 0 & $0.0 \pm 0.0 \mathrm{a}$ & $0.0 \pm 0.0 \mathrm{a}$ \\
\hline- & 2 & 0.1 & 83 & $0.8 \pm 0.2 \mathrm{bcd}$ & $0.8 \pm 0.2 \mathrm{abc}$ & 83 & $1.2 \pm 0.3 \mathrm{de}$ & $3.1 \pm 1.1 \mathrm{fgh}$ \\
\hline - & 2 & 0.2 & 67 & $0.7 \pm 0.2 \mathrm{bcd}$ & $0.7 \pm 0.2 \mathrm{abc}$ & 66 & $0.7 \pm 0.2$ abcde & $2.5 \pm 0.8 \mathrm{cdefgh}$ \\
\hline - & 2 & 0.25 & 67 & $0.7 \pm 0.2 \mathrm{bcd}$ & $0.7 \pm 0.2 \mathrm{abc}$ & 100 & $1.2 \pm 0.2 \mathrm{de}$ & $2.7 \pm 0.7$ defgh \\
\hline- & 4 & 0.1 & 33 & $0.3 \pm 0.2 \mathrm{ab}$ & $0.5 \pm 0.3 \mathrm{ab}$ & 50 & $0.5 \pm 0.2 \mathrm{abcd}$ & $1 \pm 0.5$ abcde \\
\hline - & 4 & 0.2 & 67 & $0.7 \pm 0.2 \mathrm{bcd}$ & $1.0 \pm 0.4 \mathrm{abcd}$ & 66 & $0.7 \pm 0.2$ abcde & $1.7 \pm 0.8$ abcdefg \\
\hline - & 4 & 0.25 & 100 & $1.0 \pm 0.0 \mathrm{cde}$ & $1.2 \pm 0.2$ abcde & 33 & $0.3 \pm 0.2 \mathrm{abc}$ & $1.5 \pm 1.0 \mathrm{abcdefg}$ \\
\hline \multirow[t]{3}{*}{ - } & 8 & 0.1 & 33 & $0.3 \pm 0.2 \mathrm{ab}$ & $0.8 \pm 0.5 \mathrm{abc}$ & 33 & $0.3 \pm 0.2 \mathrm{abc}$ & $1.3 \pm 1.0 \mathrm{abcdef}$ \\
\hline & 8 & 0.2 & 50 & $0.5 \pm 0.2 \mathrm{abc}$ & $2.0 \pm 1.1 \mathrm{bcdef}$ & 33 & $0.3 \pm 0.2 \mathrm{abc}$ & $1.7 \pm 1.1$ abcdefg \\
\hline & 8 & 0.25 & 50 & $0.5 \pm 0.2 \mathrm{abc}$ & $1.0 \pm 0.6 \mathrm{abcd}$ & 17 & $0.2 \pm 0.2 \mathrm{ab}$ & $0.2 \pm 0.2 \mathrm{ab}$ \\
\hline
\end{tabular}

significant increase in the number of shoots for WPM medium combinations and it failed to show any response in further passages. However, enhancement in shoot number was observed in a few combinations of the MS medium. The combinations like MS medium supplemented with BAP $(4 \mu \mathrm{M})+\mathrm{KN}(8 \mu \mathrm{M})$ and MS + BAP $(8 \mu \mathrm{M})+\mathrm{TDZ}$ $(0.1 \mu \mathrm{M})$ resulted in formation of healthy multiple shoots with an increase in number after the second subculture, but it reduced in subsequent passages. KN $(8 \mu \mathrm{M})$ with TDZ $(0.2 \mu \mathrm{M})$ decreased the number of shoots per node and it was lowest as compared to other combinations, but it resulted in developing healthy long shoots. However, BAP $(8 \mu \mathrm{M})$ with TDZ $(0.2 \mu \mathrm{M})$ resulted in a maximum number of shoots among all the tested combinations, and there was an increase in shoot number after each subculture. A threefold increase in shoot number was observed after second subculture reaching up to an average of 6.1 shoots. The number of shoots reached 10.2 after the fifth subculture
(Fig. 1D), and healthy multiple shoots with well-developed leaves had formed (Fig. 3). In the same combination ie. BAP $(8 \mu \mathrm{M})$ with TDZ $(0.2 \mu \mathrm{M})$ the multiplication rate was checked from the first subculture. The number of shoots formed per subculture for a node was counted and the number of new nodes formed for per in vitro shoot. It was observed that a single node resulted in developing 2 to 6 shoots with 8 to 11 nodes. Thus, the average of total number of shoots and nodes formed per node in the first subculture was 2.2 shoots and 6.8 nodes and in the second subculture it increased to 3.1 shoots and 10.9 nodes. This indicated that the number of shoots and nodes increased at each subculture, but with a slow multiplication rate. After the fifth subculture, the shoots were harvested and placed in rooting media.

\section{In vitro rooting}

Since MS medium was effective for forming the maximum 


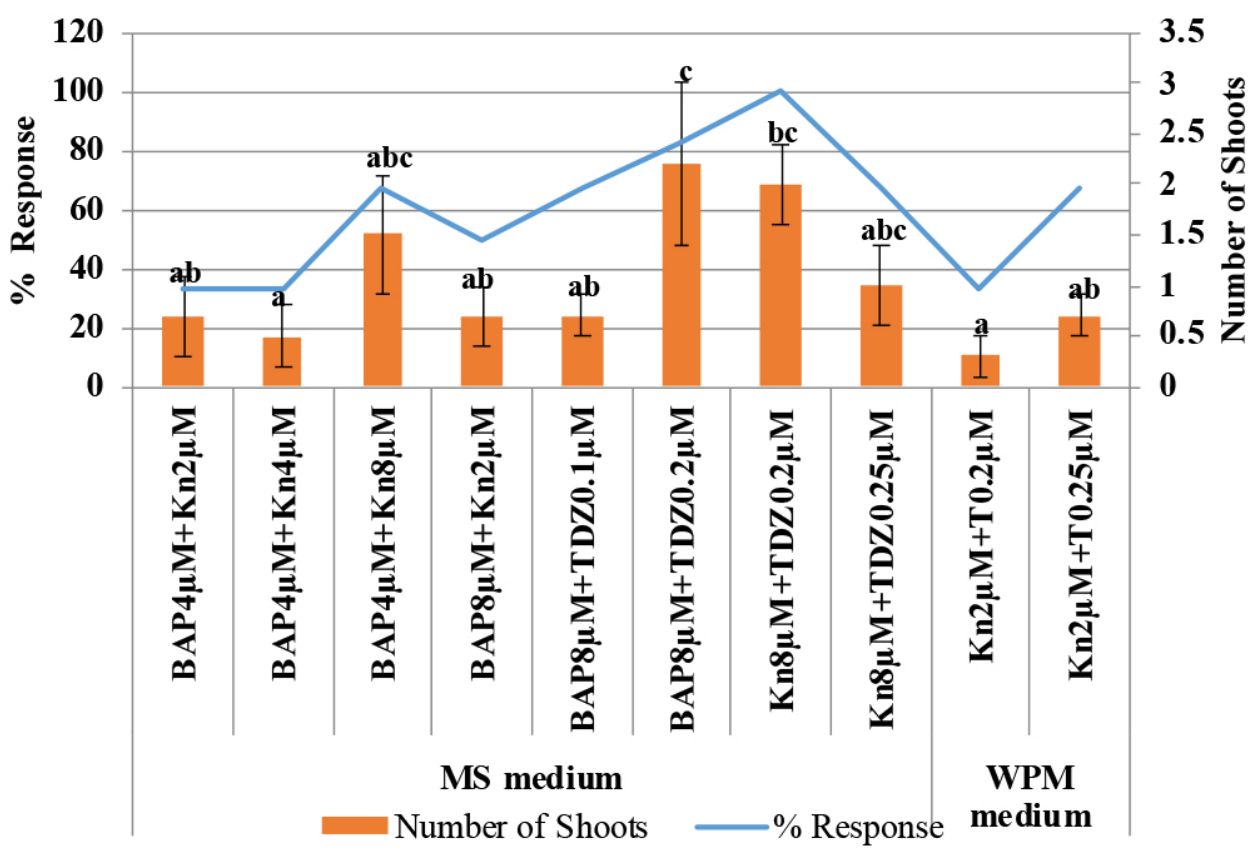

Fig. 2. Effect of cytokinins on shoot number from in vitro nodes of S. suaveolens in MS and WPM medium after first subculture. Mean values followed by different superscript letters are significantly different at $p \leq 0.05$ according to Duncan's Multiple range test with six replicates in each experiment.

shoot number, it was utilised for in vitro rooting of shoots. Single elongated shoots when placed in plant growth regulator-free half and full-strength MS medium for rooting resulted in poor response (Table 2). However, when MS medium was fortified with different concentrations of IBA and NAA the response differed. In half-strength MS liquid medium fortified with IBA $(2.5 \mu \mathrm{M}), 100 \%$ rooting frequency with a maximum number (9.3) of roots per shoot (Fig. 1E) was observed. When the static medium was fortified with IBA $(1 \mu \mathrm{M})$, a maximum number of roots (8.8) was induced with $66 \%$ rooting, which was significantly lower compared to liquid medium. The addition of NAA in half-strength medium (liquid and static) resulted in

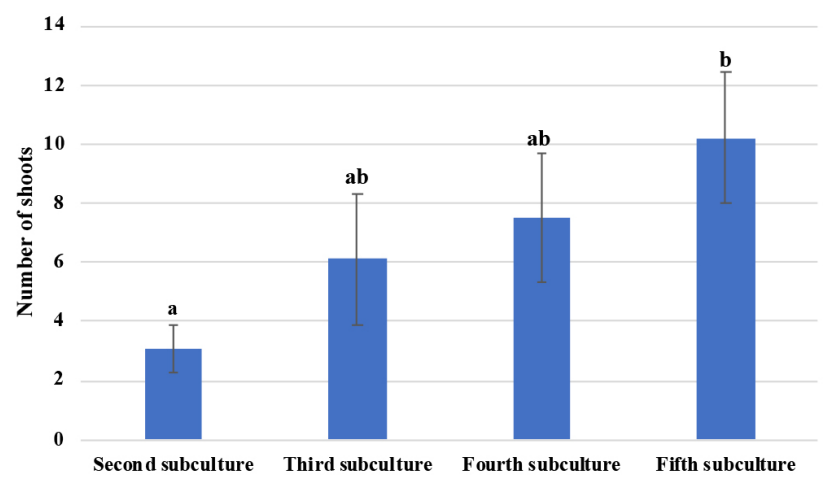

Fig. 3. Synergistic effect of MS + BAP $(8 \mu \mathrm{M})+$ TDZ $(0.2 \mu \mathrm{M})$ on shoot number after second, third, fourth and fifth subculture. Means values followed by different superscript letters within a column are significantly different at $p \leq 0.05$ according to Duncan's Multiple range test with 10 replicates in each experiment. an increase in the rooting frequency and root length, but the number of forming roots was less (Table 2). When the regenerated shoots were placed in full strength MS medium, the percent rooting frequency was significantly higher in liquid medium fortified with IBA compared to static medium (Table 2), as the latter produced less roots with reduced length. Incorporating NAA in liquid full strength medium, the rooting frequency dropped slightly, on the other hand in static medium at $2 \mu \mathrm{M}$ it increased to $100 \%$ (Table 2), but the number of roots formed was lower. Thus for S. suaveolens, liquid medium was found superior to static in terms of the number of roots formation, and also half strength was superior compared to full strength MS medium.

\section{Hardening of plantlets}

The well-developed plantlets were transferred to different natural planting substrates for hardening under greenhouse conditions. Before transferring of plantlets to each substrate, data for shoot and root length, plant height was initially recorded. The percent survival and different growth parameters were recorded in each substrate after four weeks of transfer. A significant increase in growth was observed in plants, but the response in terms of growth varied among substrates. The maximum percent survival $(100 \%)$ was observed in cocopeat/soil (Fig. 1F), which was maximum among all the other substrates tried, followed by cocopeat/sand/soil with $75 \%$ response. In cocopeat/soil substrate, a maximum shoot length of $8.2 \mathrm{~cm}$ was observed (Fig. 1G), whereas maximum root length was observed in cocopeat:sand substrate. The overall plant height was 
Table 2. Effect of half and full strength MS medium fortified with IBA and NAA on root induction of S. suaveolens after four weeks. Values represent mean \pm S.E of six replicates in each experiment. Means values followed by different superscript letters within a column are significantly different at $p \leq 0.05$ according to Duncan's Multiple range test

\begin{tabular}{|c|c|c|c|c|c|c|c|c|}
\hline Medium & $\begin{array}{c}\text { Auxin } \\
(\mu \mathrm{M})\end{array}$ & NAA & Rooting (\%) & $\begin{array}{l}\text { Number of } \\
\text { roots per } \\
\text { shoot } \\
\text { Liquid }\end{array}$ & $\begin{array}{l}\text { Root length } \\
\text { (cm) }\end{array}$ & Rooting (\%) & $\begin{array}{l}\text { Number of } \\
\text { roots per } \\
\text { shoot } \\
\text { Static }\end{array}$ & $\begin{array}{l}\text { Root length } \\
\text { (cm) }\end{array}$ \\
\hline \multirow{9}{*}{$\begin{array}{l}\text { Half } \\
\text { strength }\end{array}$} & 0 & 0 & 33 & $0.5 \pm 0.3 \mathrm{a}$ & $0.9 \pm 0.6 \mathrm{ab}$ & 50 & $2.0 \pm 0.9 \mathrm{ab}$ & $0.8 \pm 0.4 \mathrm{ab}$ \\
\hline & 1 & & 50 & $1.5 \pm 0.8 \mathrm{ab}$ & $1.1 \pm 0.5 \mathrm{ab}$ & 66 & $8.8 \pm 3.8 \mathrm{~cd}$ & $1.0 \pm 0.4 \mathrm{ab}$ \\
\hline & 2 & & 100 & $5.5 \pm 1.7 b c$ & $4.1 \pm 0.9$ ef & 50 & $1.0 \pm 0.4 \mathrm{a}$ & $0.6 \pm 0.2 \mathrm{a}$ \\
\hline & 2.5 & & 100 & $9.3 \pm 0.8 \mathrm{~d}$ & $0.8 \pm 0.1 \mathrm{ab}$ & 33 & $1.2 \pm 0.7 \mathrm{ab}$ & $0.2 \pm 0.1 \mathrm{a}$ \\
\hline & 5 & & 50 & $4.0 \pm 1.8 \mathrm{ab}$ & $0.7 \pm 0.1 \mathrm{ab}$ & 50 & $1.0 \pm 0.4 \mathrm{a}$ & $0.2 \pm 0.1 \mathrm{a}$ \\
\hline & & 1 & 100 & $2.8 \pm 0.5 \mathrm{ab}$ & $4.3 \pm 0.6 \mathrm{f}$ & 100 & $2.3 \pm 0.4 \mathrm{ab}$ & $2.3 \pm 0.5 \mathrm{bcd}$ \\
\hline & & 2 & 100 & $3.0 \pm 0.5 \mathrm{ab}$ & $1.4 \pm 0.4 \mathrm{abc}$ & 100 & $3.2 \pm 0.4 \mathrm{ab}$ & $0.8 \pm 0.2 \mathrm{ab}$ \\
\hline & & 2.5 & 66 & $2.2 \pm 1.1 \mathrm{ab}$ & $3.9 \pm 1.3 \mathrm{def}$ & 66 & $2.2 \pm 0.7 \mathrm{ab}$ & $1.2 \pm 0.5 \mathrm{ab}$ \\
\hline & & 5 & 100 & $4.5 \pm 0.8 \mathrm{ab}$ & $2.7 \pm 0.3 \mathrm{cde}$ & 66 & $2.5 \pm 1.0 \mathrm{ab}$ & $0.9 \pm 0.4 \mathrm{ab}$ \\
\hline \multirow{9}{*}{$\begin{array}{l}\text { Full } \\
\text { strength }\end{array}$} & 0 & 0 & 0 & $0.0 \pm 0.0 \mathrm{a}$ & $0.0 \pm 0.0 \mathrm{a}$ & 33 & $0.3 \pm 0.2 \mathrm{a}$ & $0.3 \pm 0.2 \mathrm{abc}$ \\
\hline & 1 & & 33 & $1.2 \pm 0.7 \mathrm{ab}$ & $1.0 \pm 0.7$ abcde & 0 & $0.0 \pm 0.0 \mathrm{a}$ & $0.0 \pm 0.0 \mathrm{a}$ \\
\hline & 2 & & 33 & $0.3 \pm 0.2 \mathrm{a}$ & $0.2 \pm 0.2 \mathrm{ab}$ & 50 & $0.7 \pm 0.3 \mathrm{a}$ & $0.5 \pm 0.4 \mathrm{abc}$ \\
\hline & 2.5 & & 100 & $6.3 \pm 1.1 \mathrm{~cd}$ & $4.2 \pm 0.8 \mathrm{f}$ & 66 & $2.0 \pm 0.9 \mathrm{ab}$ & $1.1 \pm 0.4 \mathrm{abcd}$ \\
\hline & 5 & & 100 & $6.8 \pm 1.3 \mathrm{~d}$ & $2.5 \pm 0.7 \mathrm{ef}$ & 66 & $1.3 \pm 0.5 \mathrm{ab}$ & $1.2 \pm 0.7 \mathrm{abcd}$ \\
\hline & & 1 & 66 & $2.3 \pm 0.9 \mathrm{ab}$ & $2.3 \pm 0.9 \mathrm{de}$ & 66 & $2.2 \pm 0.7 \mathrm{ab}$ & $0.6 \pm 0.2 \mathrm{abcd}$ \\
\hline & & 2 & 66 & $3.7 \pm 1.8 \mathrm{bc}$ & $1.8 \pm 0.8$ bcde & 100 & $2.0 \pm 0.5 \mathrm{ab}$ & $1.6 \pm 0.4 \mathrm{abcd}$ \\
\hline & & 2.5 & 66 & $1.0 \pm 0.4 \mathrm{ab}$ & $2.0 \pm 0.9 \mathrm{cde}$ & 50 & $2.0 \pm 1.1 \mathrm{ab}$ & $0.4 \pm 0.2 \mathrm{abc}$ \\
\hline & & 5 & 50 & $2.0 \pm 1.1 \mathrm{ab}$ & $1.1 \pm 0.6$ abcde & 0 & $0.0 \pm 0.0 \mathrm{a}$ & $0.0 \pm 0.0 \mathrm{a}$ \\
\hline
\end{tabular}

maximum in cocopeat/sand with $17.6 \mathrm{~cm}$ followed by cocopeat/soil with $14.0 \mathrm{~cm}$ after 4 weeks of transfer (Table 3).

Cocopeat substrate resulted in a slight increase in shoot length from 3.2 to $3.6 \mathrm{~cm}$, while the root length reached from $3.3 \mathrm{~cm}$ to $4.3 \mathrm{~cm}$ (Table 3 ). The rooted plants were also transferred to a thermocol cup filled with individual sand and soil substrate, but these substrates resulted in poor response in terms of percent survival and growth. Another parameter i.e., the emergence of new leaves at the plant's apex, was observed in all of the substrates within two weeks. The leaf number was nearly the same in each substrate but there was variation in leaf length. The maximum of $3.6 \mathrm{~cm}$ leaf length was observed in cocopeat/soil substrate (Table 3).

After one month, the plants from each substrate were transferred in plastic pots filled with garden soil for further growth under greenhouse conditions. These pots were covered with polythene bags initially for 4 to 5 days and then removed. Within a week, plants failed to grow except the ones that were initially kept in cocopeat/soil substrate, as they were able to resume healthy growth. There was development of new secondary roots by the end of eight weeks. The leaves matured and there was a marked increase in shoot and root length of plants, ie., 7.4 and $11.9 \mathrm{~cm}$, whereas plant height reached $19.2 \mathrm{~cm}$ (Fig. 1H). The plants

Table 3. Hardening of S. suaveolens in different substrates. Initial measurements were performed before transfer, and final measurements were performed four weeks after transfer. Values represent mean \pm SE of eight replicates in each experiment. Means values followed by different superscript letters within a column are significantly different at $p \leq 0.05$ according to Duncan's Multiple range test

\begin{tabular}{|c|c|c|c|c|c|c|c|c|c|}
\hline Sub & $\begin{array}{c}\text { Initial } \\
\text { shoot } \\
\text { length }(\mathrm{cm})\end{array}$ & $\begin{array}{l}\text { Initial root } \\
\text { length } \\
(\mathrm{cm})\end{array}$ & $\begin{array}{l}\text { Initial } \\
\text { height } \\
(\mathrm{cm})\end{array}$ & $\begin{array}{c}\text { Sur- } \\
\text { vival } \\
(\%)\end{array}$ & $\begin{array}{l}\text { Final shoot } \\
\text { length }(\mathrm{cm})\end{array}$ & $\begin{array}{l}\text { Final root } \\
\text { length } \\
(\mathrm{cm})\end{array}$ & $\begin{array}{c}\text { Final height } \\
(\mathrm{cm})\end{array}$ & $\begin{array}{l}\text { New leaf } \\
\text { number }\end{array}$ & $\begin{array}{c}\text { Leaf length } \\
(\mathrm{cm})\end{array}$ \\
\hline & & & & 50 & & & & & \\
\hline Sand & & & & 0 & & & & & \\
\hline Soil & $5.4 \pm$ & $2.2 \pm$ & $8.0 \pm$ & 13 & & & & & $a b$ \\
\hline Coco & $7.7 \pm 0.8 \mathrm{~d}$ & $3.0 \pm 0.6 \mathrm{ab}$ & $10.7 \pm 1.1 \mathrm{~b}$ & 100 & $8.2 \pm 1.0 \mathrm{c}$ & $3.2 \pm 0.7 \mathrm{a}$ & $14.0 \pm 1.5 \mathrm{c}$ & $3.0 \pm 0.3 \mathrm{a}$ & $3.6 \pm 0.4 \mathrm{c}$ \\
\hline Coco & 0 & & $8.8 \pm 1.4 \mathrm{ab}$ & 63 & $7 c$ & & $17.6 \pm 2.4 c$ & $5.0 \pm$ & $1.9 \pm 0.4 \mathrm{abc}$ \\
\hline Cocopeat/ & $4.4 \pm 0.8 \mathrm{abc}$ & $2.4 \pm 0.5 \mathrm{a}$ & $7.1 \pm 1.2 \mathrm{ab}$ & 75 & $6.2 \pm 0.6 b c$ & $3.4 \pm 0.7 \mathrm{a}$ & $11.0 \pm 1.3 \mathrm{bc}$ & $4.0 \pm 0.2 \mathrm{a}$ & 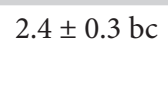 \\
\hline
\end{tabular}


were then transferred to garden pots (Fig. 1I) and kept in a greenhouse for few days and finally in open sunlight. Compared to individual substrates, combinations of these substrates, i.e. cocopeat/sand, cocopeat/soil, cocopeat/ sand/soil responded better in terms of growth. However, the cocopeat/soil (1:1) substrate proved beneficial in terms of growth and survival of S. suaveolens plants.

\section{Discussion}

In the present study, establishment of S. suaveolens shoots was done using young nodal explants and in vitro nodes for shoot multiplication. Similarly, Embelia ribes nodal explants collected from mature plants were used as the primary source of explants and multiplication was achieved from nodes of in vitro derived plantlets (Preetha et al. 2012). The type of cytokinin and its concentration depends on plant species for micropropagation of woody plants and they differ in their activity (Nikolic et al. 2006). S. suaveolens nodal explants were placed in medium fortified with different cytokinins in combinations and their effect on shoot regeneration was evaluated. It was observed that when BAP was added with $\mathrm{KN} / \mathrm{TDZ}$, the frequency of shoot regeneration improved. BAP $(8 \mu \mathrm{M})$ with $\mathrm{KN}$ $(4 \mu \mathrm{M})$ and BAP $(2 \mu \mathrm{M})$ with TDZ $(0.2 \mu \mathrm{M})$ resulted in a maximum $100 \%$ response with 1.5 shoots. Similar findings have been reported in rose cultivars (Saklani et al. 2015) and Acacia catechu (Manisha et al. 2002), where MS medium supplemented with BAP and $\mathrm{KN}$ resulted in highest number of shoots and in Stevia rebaudiana (Ghauri et al. 2013). BAP and TDZ combinations resulted in an optimum response. Regarding in vitro nodes, a maximum of 3.3 nodes was formed in BAP $(8 \mu \mathrm{M})$ with TDZ $(0.2$ $\mu \mathrm{M})$ after 4 weeks in S. suaveolens. A study on a similar species, i.e. Stereospermum suaveolens (Shukla et al.2012), obtained a maximum number of nodes per micro shoot (3.6) in MS supplemented with $0.44 \mu \mathrm{M}$ BAP and $100.0 \mathrm{mg}$ $\mathrm{L}^{-1}$ activated charcoal. In our study, when WPM medium was tested in S. suaveolens the BAP and $\mathrm{KN}$ combination was effective in terms of shoot regeneration, and BAP (4 $\mu \mathrm{M})+\mathrm{KN}(8 \mu \mathrm{M})$ resulted in a maximum shoot number. These results are similar to tose found for Cinnamomum camphora (Nirmal Babu et al. 2003) where WPM with BA $(13.32 \mu \mathrm{M})$ and $\mathrm{KN}(4.65 \mu \mathrm{M})$ resulted in maximum shoot formation.

In the present work, the in vitro nodes from S. suaveolens shoots were excised and subcultured for enhancing shoot number in up to five passages. Similarly, the nodal segments from in vitro axillary shoots were subcultured for shoot multiplication in up to eight passages in Gmelina arborea (Naik et al. 2003). The in vitro nodes formed long and healthy shoots in combination of MS + BAP $(8 \mu \mathrm{M})$ with TDZ $(0.2 \mu \mathrm{M})$ with significant increase in number of shoots in each subculture passage. An increase of axillary shoots in consecutive excision-subculture cycles was also been reported for Ocimum kilimandscharicum (Saha et al. 2010) and the results are also analogous to Arthrocarpus communis (Mariska et al. 2004), where BAP with TDZ had an effect on shoot growth. Thus, MS medium was shown to be effective compared to WPM medium in terms of shoot multiplication in S. suaveolens. Similarly, for Vaccinium vitis-idaea, modified MS medium was better than WPM medium for multiplication of shoots (Debnath, McRae 2001) and for $\mathrm{G} \times \mathrm{N} 15$ (hybrid almond $\times$ peach), MS medium was superior to Quoirin and Lepoivre medium (Arab et al. 2014).

Medium strength, type of auxins and their concentrations are important factors for root induction. In the present study, half and full-strength MS medium were able to induce roots, but half strength medium was superior to full strength medium, which was similar to the findings reported for Gardenia latifolia (Reddy, Saritha 2013) and Terminalia bellerica (Phulwaria et al. 2012). It is known that IBA and NAA stimulates induction of adventitious roots (Copes, Mandel 2000) and they have been utilised for root induction in Rauwolfia serpentina (Pandey et al. 2010), sugarcane (Tolera 2016; Rahman et al. 2018), Tagetes erecta (Ullah et al. 2013) and also tree species like Sterculia urens (Hussain et al. 2008) and Balanites aegyptica (Mansor et al.2003). In S. suaveolens, both of the auxins (IBA and NAA) were able to induce roots, but compared to NAA, IBA was effective in inducing the highest number of roots (9.3) at $2.5 \mu \mathrm{M}$. Similarly, IBA was effective for in vitro root induction in gerbera (Navya Swetha et al. 2018). Also, both liquid and static MS medium were able to induce roots, but liquid medium was significantly was superior to static in terms of number of roots in S. suaveolens. There are reports that rooting can be obtained in solid medium, but better results are obtained in liquid media as observed in blueberry (Zimmerman, Broome 1980). Secondly, in liquid medium the uptake of nutrients is more effective through whole surface and leads to enhanced shoot and root growth (Sandal et al. 2001).

The final stage of micropropagation involves transferring in vitro rooted plantlets from the aseptic environment to soil media, to function as independently growing plantlets (Dev et al. 2019). In S. suaveolens the growth and survival of plants was successfully done under greenhouse conditions. Similarly in Cassia sophera regenerated plantlets were successfully transferred to greenhouse conditions with a 90\% survival rate (Parveen, Shahzad 2010). Type of potting mixture used during acclimatisation is one of the important factors determining the survival percentage of the plants (Kaur et al. 2011). It has been observed that hardening medium greatly influenced growth parameters (Kashyap, Dhiman 2011). There are different planting substrates that have been employed for hardening of in vitro raised plants by various workers. Soil/sand and farmyard manure has been used for banana (Ahmed et al. 2014), cocopeat/ sand for Garcinia indica (Chabukswar, Deodhar 2005) 
and cocopeat/coconut husk for Dendrobium (Muna et al. 2016). Therefore in S. suaveolens, also different substrates were utilised for hardening. There was an increase in plant height, shoot and root length, number of leaves, and their length in each substrate after one month. Similar growth parameters were studied in Dendrobium (Muna et al. 2016) and growth was observed in terms plant height, leaf number etc.

Several researchers have successfully hardened plantlets in different substrates. In Santalum album (Singh et al. 2016) the plantlets were hardened in plastic cups containing cocopeat, sand and soil in the ratio of 1:1:1 in the controlled environment under greenhouse conditions. More than $80 \%$ plants survival was achieved when tissue culture raised plantlets of Stereospermum personatum (Shukla et al. 2009) were transferred to net pots containing cocopeat in a greenhouse. In our study, the cocopeat/soil proved to be optimum for hardening with $100 \%$ survival of plants. Individual sand and soil substrate in S. suaveolens resulted in poor response in terms of growth and survival. Similarly, sand/soil proved to be a poor combination for Gloxinia (Kashyap, Dhiman 2011) plants, as compaction of roots was observed because of poor water holding capacity that resulted in dry media.

Thus, it can be concluded that direct shoot regeneration of $S$. suaveolens can be possible through nodal explants and applying repeated excision and subculturing of in vitro nodes proved to be effective in forming multiple shoots in MS medium. The in vitro shoots were rooted in MS medium and plantlets were successfully hardened under greenhouse conditions. The present protocol can be used for propagating and conserving this valuable medicinal species.

\section{Acknowledgements}

The authors are thankful to University Grant Commission (UGC), New Delhi for providing financial assistance as JRF (Junior Research Fellowship) in Major Research Project and Rajpipla Forest Division for supplying saplings of S.suaveolens.

\section{References}

Arab M.M., Yadollahi A., Shojaieyan A., Shokri S., Ghojah S.M. 2014. Effects of nutrient media, different cytokinin types and their concentrations on in vitro multiplication of $G \times$ N15(Hybrid of almond $\times$ peach) vegetative rootstock. J. Genetic Eng. Biotechnol. 12: 81-87.

Ahmed S., Sharma A., Bhushan, B.W., Bakshi V.K.P., Singh A.K. 2014. Studies on hardening and acclimatization of micropropagated plantlets of banana cv. Grand Naine. Bioscan 9: 965-967.

Batra A., Sardana J., Audichya M., Sharma M., Zulfikar A.D. 2000. Tissue culture: An indispensable component of biotechnology for plant improvement. In: Khan I.A., Khanum A. (Eds.) Role of Biotechnology in Medicinal and Aromatic Plants. Vol. 3. Ukaaz Publications, Hyderabad, pp. 195-200.

Baul T.K. 2006. Propagation and growth performance of three important wild tree species of medicinal values. MSc Thesis, Institute of Forestry and Environmental Sciences, University of Chittagong, Bangladesh.

Behera L.K., Gunaga R.P., Sinha S.K., Sukahdiya M., Dholariya C.A., Prajapati V.M. 2019. Stereospermum chelonoides: Prospective of a lesser known and medicinal tree. Van Sangyan 6: 1-6.

Chabukswar M.M., Deodhar M.A. 2005. Rooting and hardening of in vitro plantlets of Garcinia indica Chois. Indian J. Biotechnol. 4: 409-413.

Copes D.L., Mandel N.L. 2000. Effects of IBA and NAA treatments on rooting Douglas-fir stem cuttings. New Foests 20: 249-257.

Cui Y., Deng Y., Zheng K., Hu X., Zhu M., Deng X., Xi R. 2019. An efficient micropropagation protocol for an endangered ornamental tree species (Magnolia sirindhorniae Noot. \& Chalermglin) and assessment of genetic uniformity through DNA markers. Sci. Rep. 9: 9634.

Debnath S.C., McRae K.B. 2001. In vitro culture of lingonberry (Vaccinium vitis-idaea L.): The influence of cytokinins and media types on propagation. Small Fruits Rev. 1: 3-19.

Dev R., Singh S. K., Dayal V., Kumar K., Singh T. 2019. Standardization of in vitro hardening strategies for tissue cultured wine grape (Vitis vinifera L.) genotypes. Int. J. Curr. Microbiol. Appl. Sci. 8: 2108-2117.

Dhawan V., Saxena S. 2004. Cloning forestry species. In: Srivastava P.S., Narula A., Srivastava S. (Eds.) Plant Biotechnology and Molecular Markers. Anamaya Publishers, New Delhi, pp. 183-194.

Ghauri E.G., Afridi M.S., Marwat G.A., Rahman I., Akram M. 2013. Micropropagation of Stevia rebaudiana bertoni through root explants. Pakistan J. Bot. 45: 1411-1416.

Girgzde E., Samsone I. 2017. Effect of cytokinins on shoot proliferation of silver birch (Betula pendula) in tissue culture. Environ. Exp. Biol. 15: 1-5.

Giri C.C., Shyamkumar B., Anjaneyuu C. 2004. Progress in tissue culture, genetic transformation and applications of biotechnology to trees: An overview. Trees 18: 115-135.

Hussain T.M., Thummala C., Ghanta R.G. 2008. Micropropagation of Sterculia urens Roxb. an endangered tree species from intact seedlings. African J. Biotechnol. 7: 95-101.

Kashyap B., Dhiman S. 2011. Effect of media on hardening of in vitro multiplied plantlets of gloxinia and saintpaulia under low cost polytunnels. Int. J. Farm Sci. 1: 63-67.

Kaur H., Anand M., Goyal D. 2011. Optimization of potting mixture for hardening of in vitro raised plants of Tylophora indica to ensure high survival percentage. Int. J. Medic. Arom. Plants 1: 83-88.

Mahadevappa P., Chapeyilkumaran R., Venkatarangaiah K., Sathyanarayana R. 2014. Influence of different cytokinins on direct shoot regeneration from the different explants of Carthamus tinctorious L. var. Annigeri-2 (a high oil- yielding variety). Ann. Biol. Res. 5: 14-20.

Manisha T., Sharma D., Kanwar K., Kant A. 2002. In vitro regeneration of Acacia catechu Willd. From callus and mature nodal explants - An improved method. Indian J. Exp. Biol. 40: 850-853.

Mansor N., Ismalia D., Yayekene G.D. 2003. In vitro multiplication of the semiarid forest tree, Balanites aegyptica (L.) Del. African J. Biotechnol. 2: 421-424.

Mariska I., Supriati Dan Y., Hutami S. 2004. Mikropropagasi sukun (Arthocarpus communis Forst), tanaman sumber karbohidrat alternatif. Kumpulan Makalah Seminar Hasil Penelitian. BB- 
BIOGEN Hal, pp. 180-188.

Muna S., Beura S.K., Biswal M., Taria B., Sahu P. 2016. Standardization of media combinations for hardening of orchid Dendrobium spp. cv. Sonia-17. Int. J. Agric. Sci. 8: 1042-1044.

Murkute A.A., Patil S., Singh S.K. 2004. In vitro regeneration in pomegranate cv. Ganesh from mature trees. Indian J. Hortic. 61: 206-208.

Naik D., Vartak V., Bhargava S. 2003. Provenance- and subculture-dependent variation during micropropagation of Gmelina arborea. Plant Cell Tissue Organ Cult. 73: 189-195.

Navya Swetha T., Girwani A., Manohar Rao A., Saidaiah P. 2018. To standardise the optimum concentration of auxins (NAA and IBA) for better rooting of shoots under in vitro conditions. Acta Sci. Agricult. 2: 58-60.

Nikolić R., Mitić N., Miletić R., Nešković M. 2006. Effect of cytokinins on in vitro seed germination and early seedling morphogenesis in Lotus corniculatus L. J. Plant Growth Regul. 25: 187-194.

Nirmal Babu K., Sajina A., Minooo D., John C.Z., Mini P.M., Tushar K.V., Rema J., Ravindran P.N. 2003. Micropropagation of camphor tree (Cinnamomum camphora). Plant Cell Tissue Org. Cult. 74: 179-183.

Panda B.M., Mehta U.J., Hazra S. 2016. Micropropagation of Semecarpus anacardium L. from mature tree derived nodal explants. Plant Biosyst. 150: 942-952.

Pandey V.P., Cherian E., Patani G. 2010. Effect of growth regulators and culture conditions on direct root induction of Rauwolfia serpentine L. (Apocynaceae) Benth by leaf explants. Tropical J. Pharm. Res. 9: 27-34.

Parveen S., Shahzad A. 2010. TDZ induced high frequency shoot regeneration in Cassia sophera Linn. via cotyledonary node explants. Physiol. Mol. Biol. Plants 16: 201-206.

Phulwaria M., Rai M.K., Harish, Gupta A.K., Ram K., Shekhawat N.S. 2012. An improved micropropagation of Terminalia bellirica from nodal explants of mature tree. Acta Physiol. Plant. 34: 299-305.

Preetha T.S., Hemanthakumar A.S., Krishnan P.N. 2012. Effect of plant growth regulators on high frequency in vitro multiplication of a vulnerable woody medicinal climber Embelia ribes Burm.f. J. Med. Plants Res. 6: 4011-4018.

Rahman M.M., Ivy N.A., Mian M.A., Rasul M.G., Hossain M.M., Rahman M.A. 2018. Effect of auxin (NAA, IBA and IAA) in root regeneration through in vitro culture of sugarcane. Int. J. Plant Biol. Res. 6: 1109.

Rathore P., Suthar R., Purohit S.D. 2008. Micropropagation of Terminalia bellerica Roxb. from juvenile explants. Indian J. Biotechnol. 7: 246-249.

Reddy Y.M., Saritha K.V. 2013. In vitro clonal propagation of Gardenia latifolia Ait.: a toy making woody tree. Agrofor. Syst. 87: 591-598.

Saha S., Dey P., Ghosh T. 2010. Micropropagation of Ocimum kilimandscharicum Guerke (Labiatae). Acta Biol. Cracov. Ser. Bot. 52:50-58.

Saklani K., Hem P., Rawat V. 2015. Micropropagation of rose cultivars: biotechnological application to floriculture. J. Environ. Res. Dev. 10: 40-46.

Sandal I., Bhattacharya A., Ahuja P.S. 2001. An efficient liquid culture system for tea shoot proliferation. Plant Cell Tissue Organ Cult. 65: 75-80.

Sharma S., Rathi N., Kamal B., Pundir D., Kaur B., Arya S. 2010. Conservation of biodiversity of highly important medicinal plants of India through tissue culture technology - a review. Agric. Biol. J. North Amer. 1: 827-833.

Sharma U., Kataria V., Shekhawat N.S. 2017. In vitro propagation, ex vitro rooting and leaf micromorphology of Bauhinia racemosa Lam.: a leguminous tree with medicinal values. Physiol. Mol. Biol. Plants 23: 969-977.

Shukla S., Shukla S.K., Mishra S.K. 2009. In vitro plant regeneration from seedling explants of Stereospermum personatum DC: a medicinal tree. Trees 23: 409-413.

Shukla S., Shukla S.K., Mishra S.K. 2012. In vitro regeneration of multipurpose medicinal tree Stereospermum suaveolens - factors controlling the in vitro generation. J. Biotechnol. Biomater. 13: 1-3.

Singh A.K., Chand S., Pattnaik S., Chand P.K. 2002. Adventitious shoot organogenesis and plant regeneration from cotyledons of Dalbergia sissoo Roxb. a timber yielding tree legume. Plant Cell Tissue Organ Cult. 68: 203-209.

Singh M., Sonkusale S., Niratker Ch., Shukla P. 2014. Micropropagation of Shorea robusta: an economically important woody plant. J. Forest Sci. 60: 70-74.

Singh C.K., Raj S.R., Jaiswal P.S., Patil V.R., Punwar B.S., Chavda J. C. 2016. Subash N. Effect of plant growth regulators on in vitro plant regeneration of sandalwood (Santalum album L.) via organogenesis. Agrofor. Syst. 90: 1-11.

Tan S.N., Tee C.S., Wong H.L. 2018. Multiple shoot bud induction and plant regeneration studies of Pongamia pinnata. Plant Biotechnol. 35: 325-334.

Tolera B. 2016. Effects ofn acetic acid (NAA) and indole-3-butyric acid (IBA) on in vitro rooting of sugarcane (Saccharum officinarum L.) microshoots. J. Biotechnol. Biomater. 6: 1-5.

Trivedi D.R., Joshi A.G. 2014a. Studies on seed germination of Stereospermum suaveolens with respect to different parameters. Environ. Exp. Biol. 12: 33-37.

Trivedi D.R, Joshi A.G. 2014b. In vitro shoot regeneration of Stereospermum suaveolens DC. using cotyledonary node and nodal explants. Plant Tissue Cult. Biotechnol. 24: 235-246.

Ullah Z., Abbas S.J., Naeem N., Lutfullah G., Malik T., Khan M.A.U., Khan I. 2013. Effect of indolebutyric acid (IBA) and napthaleneacetic acid (NAA) plant growth regulators on marigold (Tagetes erecta L.). African J. Agric. Res. 8: 40154019.

Van Staden J., Zazimalova E., George E.F. 2008. Plant growth regulators II: Cytokinins, their analogues and antagonists. In: George E.F., Hall M.A., De Klerk G.J. (Eds.) Plant Propagation by Tissue Culture. Springer, Netherlands, pp. 205-226.

Yasodha R., Sumanthi R., Gurumurthi K. 2004. Micropropagation for quality propagule production in plantation forestry. Indian J. Biotechnol. 3: 159-170.

Zimmerman R.H., Broome O.C. 1980. Blueberry micropropagation. In: Proceedings of the conference on nursery production of fruit plants through tissue culture, applications and feasibility, USDA, SEA Agricultural Research, pp. 1144-1147. 